\title{
Preparation and characterization of protein isolate and biodiesel from garden cress seed
}

\author{
Rehab Farouk Mohammed Ali \\ Department of Biochemistry, Faculty of Agriculture, Cairo University, 12613, Giza, Egypt \\ *Corresponding author at: Department of Biochemistry, Faculty of Agriculture, Cairo University, 12613, Giza, Egypt. \\ Tel.: +2.0128.2959994; fax: +2.023.7742600.E-mail address: malkanany@yahoo.com (R.F.M. Ali).
}

\begin{tabular}{l} 
ARTICLE INFORMATION \\
\hline Received: 24 November 2012 \\
Received in revised form: 23 January 2013 \\
Accepted: 27 January 2013 \\
Online: 30 June 2013 \\
KEYWORDS \\
\hline Seed \\
Biodiesel \\
Erucic acid \\
Amino acid \\
Garden cress \\
Triglycerides \\
\hline
\end{tabular}

\section{Introduction}

Garden cress (Lepidiumsativum Linn.) is an annual herb, belonging to Brassicaceae family that is native to Egypt and west Asia but is widely cultivated in hot temperate climates throughout the world for various culinary and medicinal uses [1]. Garden cress $(\mathrm{Gc})$ is a fast-growing edible plant. Seeds, leaves and roots of Gc are of economic importance; however, the crop is mainly cultivated for seeds. Garden cress is an important medicinal crop in India [2]. Garden cress seeds are brownish red in color and oval in shape. Morphologically, Gc seeds resemble that of an oil seed with the dicotyledonous endosperm accounting to $80-85 \%$ of the seed matter, the seed coat account for $12-17 \%$ and the embryo for $2-3 \%$ of the seeds, respectively. The Gc seeds are bitter, thermogenic, depurative, rubefacient, galactogogue, tonic, aphrodisiac, ophthalmic, antiscorbutic, antihistaminic and diuretic. They are useful in the treatment of asthma, coughs with expectoration, poultices for sprains, leprosy, skin disease, dysentery, diarrhoea, splenomegaly, dyspepsia, lumbago, leucorrhoea, scurvy and seminal weakness [3]. The seeds contain $25 \%$ of protein, $14-$ $24 \%$ of lipids, $33-54 \%$ of carbohydrates and $8 \%$ of crude fiber $[4,5]$. The carbohydrates of the garden cress seeds comprise of $90.0 \%$ non-starch polysaccharides and $10 \%$ of starch. The seed bran has high dietary fiber content and also it has high water holding capacity. Gc bran can be used as a rich source of dietary fiber [1]. Garden cress seed contains 20-25\% yellowish semidrying oil and the major fatty acid in it is alpha linolenic acid (32-34\%) [6]. Mixing garden cress oil (Gc0) with linseed oil led to significant increase in the oxidative stability of linseed oil [7]. GcO has a balanced amount of polyunsaturated fatty acids (PUFA) (46.8\%) and monounsaturated fatty acids (MUFA) (37.6\%) and also contains natural antioxidants viz., tocopherols and carotenoids which protect the oil from rancidity [6]. In this respect, [8] reported that erucic acid
(C22:1; $3.0 \mathrm{wt} \%$ ), stearic acid (C18:0; $2.8 \mathrm{wt} \%)$, and arachidic acid (C20:0; $2.3 \mathrm{wt} \%$ ) were among the minor fatty acids found in garden cress oil. The effect of erucic acid has been proven in the transient decrease in platelet counts and increase in platelet size in newborn piglets fed canola oil [9]. Similar findings regarding the effect of erucic acid on platelet counts has been reported in human studies on patients with adrenoleukodystrophy [10].

The idea to use vegetable oils as fuels is more than a hundred years old. Rudolf Diesel conducted an engine tests on plant oils at the World's Exhibition in Paris in 1900 [11]. Biodiesel, defined as mono-alkyl (methyl or ethyl) esters produced from plant oils and animal fats [12] by transesterification reactions, plays a very important role as an alternative to conventional diesel. Transesterification, also called alcoholysis [13-15], has been widely used to reduce the viscosity of triglycerides and produce biodiesel.

The biodiesel transesterification reaction is very simple (Scheme 1). This is an equilibrium reaction where an organic oil, or triglyceride, can be processed into biodiesel, usually in the presence of a catalyst, and alkali such as potassium hydroxide $[15,16]$. Biodiesel, which is produced from vegetable oils, animal fats or waste cooking oils has been shown to yield lower emissions of particulate matter (PM), unburned hydrocarbon, carbon dioxide, carbon monoxide, polycyclic aromatic hydrocarbons (PAH), and nitric polycyclic hydrocarbons (nPAH) than petrodiesel [17].

The main goal of the current investigation was to evaluate the physicochemical properties of garden cress oil and its biodiesel. Moreover, the quality of garden cress protein isolate was determined by evaluating the chemical composition, amino acid composition, biological values and some of functional properties of protein isolate.

European Journal of Chemistry 


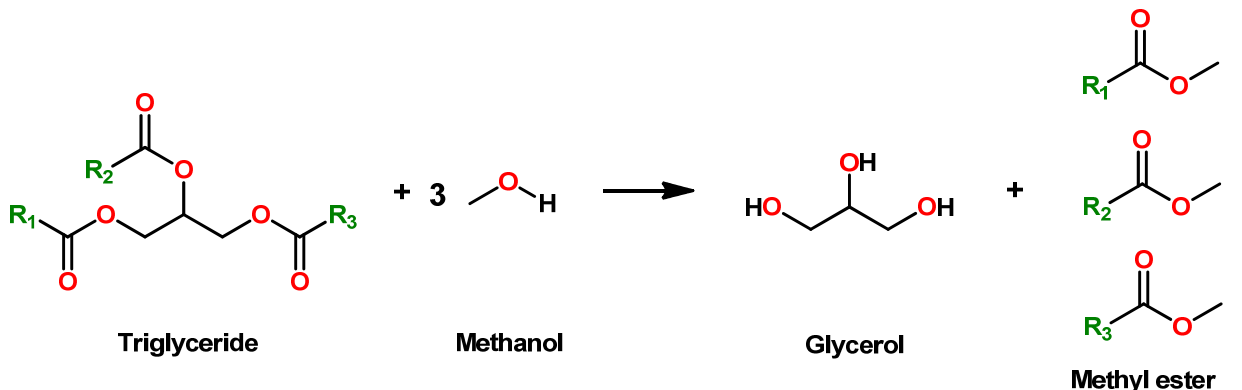

Scheme 1

\section{Experimental}

\subsection{Materials}

Garden cress (Lepidiumsativum Linn.) seeds were obtained from Harraz for Spices and Herbs Co. Cairo, Egypt. All reagents and chemicals were of analytical-reagent grade, and deionized water was utilized throughout this work.

\subsection{Methods}

\subsubsection{Oil extraction}

The extraction of oil of garden cress seeds was carried out by using chloroform:methanol $(2: 1, v: v)$ method according to the method described by Bligh and Dyer [18].

\subsubsection{Biodiesel production and purification}

Garden cress oil was used as the raw oil to react with methanol in a molar proportion of 1:6 to produce biodiesel. Sodium hydroxide of $1 \%$ on a mass base of the garden cress oil was used as the catalyst and pre-mixed with methanol by a mechanical stirrer. This mixture was thereafter added into a reacting tank to be mixed with the garden cress oil using a mechanical homogenizer in order to undergo transesterification reaction. The reaction temperature of the transesterification process was set at $60^{\circ} \mathrm{C}$ in order to prevent the vaporization of the methanol from the reacting mixture during the biodiesel production process. The reaction was allowed to proceed for $50 \mathrm{~min}$. At the end of the incubation, the mixture was transferred into a seperatory funnel, left for $24 \mathrm{~h}$ and then the biodiesel separated from the glycerol. The biodiesel was then washed with hot deionized water $\left(50{ }^{\circ} \mathrm{C}\right)$ five times to remove the glycerol, catalyst and other impurities [19-21]. The percent biodiesel yield was calculated by relating the biodiesel volume to that of the oil that underwent transesterification.

\subsubsection{Preparation of garden cress protein isolate}

The garden cress protein isolate was prepared by an isoelectric point precipitation technique as described by Ruiz and Hove [22] and Abbott [23]. The dried defatted seed suspended in distilled water containing $0.25 \% \mathrm{Na}_{2} \mathrm{SO}_{3}$ at $1: 100$ (w:v) ratio. The mixture was magnetically stirred for $1 \mathrm{~h}$ while adjusting the $\mathrm{pH}$ to 9.0 with $\mathrm{NaOH}$ solution $(4 \mathrm{M})$. Then, the mixture was centrifuged at $3500 \mathrm{rpm}$ for $15 \mathrm{~min}$ at room temperature. The supernatant was transferred into a beaker, stirred for another $30 \mathrm{~min}$, and the $\mathrm{pH}$ adjusted to 4.8 by the addition of $\mathrm{HCl}$ solution $(1.0 \mathrm{~N})$. The supernatant was left undisturbed for cold precipitation overnight at $4{ }^{\circ} \mathrm{C}$. Then, the supernatant was carefully siphoned off and the protein slurry was washed three times with distilled water by centrifuging at
$3500 \mathrm{rpm}$ for $20 \mathrm{~min}$. The precipitate was recovered by centrifugation at $3500 \mathrm{rpm}$ for $30 \mathrm{~min}$. The precipitate was washed by distilled water several times, and then neutralized by $1.0 \mathrm{M} \mathrm{NaOH}$ to $\mathrm{pH}=7$. The neutralized precipitate was dried at $50{ }^{\circ} \mathrm{C}$ for $48 \mathrm{~h}$ in an air convection oven, ground and passed through a $150 \mu \mathrm{m}$ mesh sieve.

\subsubsection{Analytical methods}

Moisture, crude oil, crude protein ( $\mathrm{N}$ x 6.25), crude fiber and ash of samples were determined as described in AOAC official methods [24].

The total carbohydrate content (on dry weight basis) was calculated by the difference $(100-(\%$ protein $+\%$ lipid $+\%$ ash + fiber).

The minerals, i.e., $\mathrm{Ca}, \mathrm{Fe}, \mathrm{Zn}, \mathrm{K}, \mathrm{Cu}, \mathrm{P}, \mathrm{Mg}$ and $\mathrm{Na}$ were determined in a dilute solution of the ashed samples by atomic absorption spectrophotometer $(3300$ Perkin-Elmer $)$ as described in AOAC official methods [24].

Amino acids were determined according to method of Moore and Stein [25]. Hydrolysis of the samples was performed in the presence of $6 \mathrm{M} \mathrm{HCl}$ at $110{ }^{\circ} \mathrm{C}$ for $24 \mathrm{~h}$ under a nitrogen atmosphere. Sulfur-containing amino acids were determined after performic acid oxidation. Tryptophan was chemically determined by the method of Miller [26].

The amino acid score (AAS) was calculated for each essential amino acid using the FAO/WHO/UNU [27] reference protein as follows:

$$
\text { AAS }=\frac{\text { Concentration of essential AA in the protein under test }}{\text { Concentration of essential AA in the FAO WHO/UNU standard }} \times 100
$$

Values for AAS lower than 100 indicate a deficiency of that amino acid. The limiting amino acid (LAA) was defined as that showing the lowest AAS value [28]. Protein efficiency ratio (PER) was estimated using the regression equation proposed by Alsmeyer [29]:

PER $=-0.468+0.454 \times$ Leucine $-0.105 \times$ Tyrosine

\subsubsection{Protein properties}

Water absorption (expressed as the amount of water retained by $100 \mathrm{~g}$ of protein) and fat absorption capacities (expressed as $\mathrm{mL}$ of oil absorbed by $100 \mathrm{~g}$ of protein) were estimated according to the procedure of Sosulski [30] and Sosulski [31], respectively. Emulsification capacity (mL oil/g protein at $\mathrm{pH}=9$ ) was determined as described by Beuchat [32]. The method of Lawhon [33] was used to determine the foam capacity at $\mathrm{pH}=9.0$ using $2 \%$ protein solution. The percentage increase in volume after $30 \mathrm{sec}$ was recorded as foam capacity. 
Table 1. Chemical composition (g) and mineral contents (mg) of garden cress seed (GcS), defatted flour (GcDF) and protein isolate (GcPI) per $100 \mathrm{~g}(\mathrm{dry}$ weight basis).

\begin{tabular}{|c|c|c|c|c|}
\hline Component (g/100 g) & $(\mathrm{GcS})^{\mathrm{a}}$ & $(\text { GcDF) })^{a}$ & $(\mathrm{GcPI})^{\mathrm{a}}$ & LSD $(p=0.05)^{e}$ \\
\hline Moisture & $5.29 \pm 1.03^{\mathrm{d}}$ & $6.53 \pm 0.85$ & $7.21 \pm 0.70$ & 1.7392 \\
\hline Crude protein ${ }^{b}$ & $25.12 \pm 2.64$ & $45.30 \pm 2.16$ & $86.90 \pm 5.66$ & 7.6226 \\
\hline Crude oil & $29.11 \pm 1.91$ & $1.60 \pm 0.18$ & $0.65 \pm 0.08$ & 2.2148 \\
\hline Crude fiber & $5.70 \pm 1.02$ & $9.68 \pm 0.45$ & $1.90 \pm 0.16$ & 1.2991 \\
\hline Ash & $4.25 \pm 0.52$ & $6.27 \pm 0.36$ & $1.64 \pm 0.23$ & 0.7415 \\
\hline Total carbohydrate c & $35.82 \pm 4.65$ & $37.15 \pm 3.99$ & $8.91 \pm 0.87$ & 7.1385 \\
\hline \multicolumn{5}{|c|}{ Mineral contents $(\mathrm{mg} / 100 \mathrm{~g})$} \\
\hline Potassium & $1251.05 \pm 3.06^{d}$ & $1671.10 \pm 2.78$ & $366.11 \pm 1.85$ & 5.2244 \\
\hline Phosphorus & $610.63 \pm 2.15$ & $815.42 \pm 0.98$ & $165.00 \pm 3.14$ & 4.5328 \\
\hline Magnesium & $346.21 \pm 3.06$ & $495.22 \pm 0.56$ & $85.60 \pm 1.04$ & 3.7835 \\
\hline Calcium & $340.35 \pm 2.03$ & $485.24 \pm 0.78$ & $92.08 \pm 0.77$ & 2.6610 \\
\hline Sodium & $40.90 \pm 0.61$ & $72.55 \pm 1.49$ & $11.20 \pm 0.29$ & 1.8870 \\
\hline Iron & $18.31 \pm 1.12$ & $31.25 \pm 0.60$ & $6.28 \pm 0.41$ & 1.5400 \\
\hline Copper & $16.10 \pm 1.66$ & $26.23 \pm 1.53$ & $4.55 \pm 0.31$ & 2.6207 \\
\hline Zinc & $13.75 \pm 0.11$ & $24.25 \pm 0.29$ & $6.45 \pm 0.58$ & 0.7586 \\
\hline
\end{tabular}

a $p \leq 0.05$.

b Crude protein $=\mathrm{N}(\%) \times 6.25$.

Carbohydrate content obtained by subtracting the sum of moisture, crude protein, oil, crude fibre and ash from $100 \%$

d Data are expressed as mean \pm SD. Values given represent means of three determinations.

e LSD: Least different significantly at $\mathrm{p} \leq 0.05$ according to Duncan's multiple range test.

\subsubsection{Fatty acid composition}

Capillary gas chromatography (HP 6890) was used for the qualitative and quantitative determinations of the fatty acids of the oil samples and reported in relative area percentages. Fatty acids were transesterified into their corresponding fatty acid methyl esters (FAMEs) by shaking a solution of oil ( $c a .0 .1 \mathrm{~g})$ in heptane $(2 \mathrm{~mL})$ with a solution of methanolic potassium hydroxide $(0.2 \mathrm{~mL}, 2 \mathrm{~N})$. The FAMEs were identified using a gas chromatograph equipped with DB-23 capillary column $(60 \mathrm{~m}$, $0.32 \mathrm{~mm}$ i.d., $0.25 \mu \mathrm{m}$ thickness) and a flame ionization detector. The nitrogen flow rate was $3 \mathrm{~mL} / \mathrm{min}$; hydrogen and air flow rates were 40 and, $450 \mathrm{~mL} / \mathrm{min}$, respectively. The oven temperature was programmed from 150 to $170{ }^{\circ} \mathrm{C}$ at a rate of $10 \mathrm{~min}$, then raised to $192{ }^{\circ} \mathrm{C}$ at a rate of $5{ }^{\circ} \mathrm{C} / \mathrm{min}$ kept isothermal for $5 \mathrm{~min}$ and then raised again to $220^{\circ} \mathrm{C}$ at a rate of $10{ }^{\circ} \mathrm{C} / \mathrm{min}$ and kept at this temperature for $3 \mathrm{~min}$. The injector and the detector temperatures were 230 and $250{ }^{\circ} \mathrm{C}$, respectively. Fatty acid methyl esters FAMEs were identified by comparing their retention times with a known fatty acid standard mixture. Peak areas were automatically computed by an integrator.

\subsubsection{Tocopherol content}

Tocopherols were quantified by HPLC according to AOCS official method Ce 8-89 [34]. Samples were dissolved in hexane to a concentration of $50-100 \mathrm{mg} / \mathrm{mL}$, filtered through $0.45 \mu \mathrm{m}$ centrifugal filters and analyzed by a Varian HPLC Pro-Star model 230 pump, model 410 autosampler, and model 363 fluorescence detector using excitation and emission wavelengths of 290 and $330 \mathrm{~nm}$, respectively. The mobile phase consisted of hexane:2-propanol (99.5:0.5, $v: v$, made fresh daily) pumped at a rate of $1 \mathrm{~mL} / \mathrm{min}$. Samples were injected by autosampler using the full loop option $(100 \mu \mathrm{L})$, and tocopherols were separated using an Inertsil (Varian) silica column $(5 \mu \mathrm{m}, 150 \mathrm{~A} 250 \mathrm{~mm} \times 4.6 \mathrm{~mm}$ i.d.). Tocopherol peaks were identified by comparison to the retention times of known reference standards. A mixture of $\alpha, \beta, \gamma$ and $\delta$ tocopherol standards was injected on each day of analysis to verify HPLC response. Samples were quantified using external standard curves. Each determination was run in triplicate and mean values are reported.

\subsubsection{Determination of the physicochemical properties of garden cress oil and biodiesel}

Moisture content, acid value, peroxide value, iodine value, saponification value and refractive index were determined according to AOAC official methods [24]. Viscosity was determined as described by Saguy et al. [35]. The specific gravity was measured in a $25 \mathrm{~mL}$ capacity specific gravity bottle at room temperature of $25 \pm 2{ }^{\circ} \mathrm{C}$ [36].

\subsubsection{Statistical analysis}

Data are expressed as mean \pm standard deviation (SD) of three replicates. The data were analyzed by analysis of variance (ANOVA) according to the procedures outlined by Gomez and Gomez [37]. Duncan's multiple range test was used to determine the differences among samples. Significant levels were defined as probabilities of 0.05 or less.

\section{Results and discussion}

\subsection{Proximate composition of garden cress seed, meal and protein isolate (dry weight basis)}

Data presented in Table 1 show the proximate composition of garden cress seed, defatted flour (meal) and protein isolateper $100 \mathrm{~g}$ (dry weight basis). The moisture content of seed flour was $5.29 \pm 1.30 \%$. This low level of moisture content is an index of stability, quality and increased shelf life of seeds [38]. Whole seeds had significantly $(p<0.05)$ the highest level of crude oil $29.11 \%$, which was higher than that reported $(22.7$ wt\%) in a previous study [8], while the lowest level of crude oil was observed in protein isolate $0.65 \%$. On the other hand garden cress meal and protein isolate had significantly the higher value of protein 45.30 and $86.90 \%$, respectively, the process of defatting doubled the protein content. The protein content of the garden cress protein isolate was approximately 3.45 and 1.91 times as high as the protein content of the whole seeds and meal, respectively. The highest $(p<0.05)$ value of crude fiber was recorded for garden cress meal 9.68\%. While protein isolate had significantly $(p<0.05)$ the lowest one $1.90 \%$. Available literature on composition of garden cress seed show that the seeds contain $25 \%$ of protein, $14-24 \%$ of lipids, $33-54 \%$ of carbohydrates and $8 \%$ of crude fiber $[4,5,39]$. Proximate composition varies depending upon plant variety, agronomic practices, stage of collection of seeds and climatic and geological condition of area from where seeds are collected [40]. The obtained results indicate that garden cress seed had significantly the highest values of fat and protein component which motivated the author to undertake in-depth studies on both types of biomolecules.

Mineral contents of garden cress seed, defatted flour (meal) and protein isolate $(\mathrm{mg} / 100 \mathrm{~g}$ dry weight basis) are presented in Table 1. 
Table 2. Amino acid compositions and protein nutritional quality of garden cress seed protein isolate.

\begin{tabular}{|c|c|c|c|c|c|}
\hline \multirow[t]{2}{*}{ Essential amino acid } & Protein isolate & FAO/WHO/UNU (1985) * & \multirow[t]{2}{*}{ Chemical score } & \multirow{2}{*}{$\begin{array}{l}\text { Non-essential } \\
\text { amino acid }\end{array}$} & \multirow{2}{*}{$\begin{array}{l}\text { Protein isolate } \\
\mathrm{g} / \mathbf{1 0 0} \mathrm{g} \text { protein }\end{array}$} \\
\hline & \multicolumn{2}{|c|}{ Amino acid content $(\mathrm{g} / \mathbf{1 0 0} \mathrm{g})$} & & & \\
\hline Histidine & 3.62 & 1.4 & 258.50 & Arginine & 3.64 \\
\hline Isoleucine & 4.77 & 4. 00 & 119.25 & Alanine & 5.20 \\
\hline Leucine & 6.95 & 7.04 & 98.70 & Aspartic acid & 12.71 \\
\hline Lysine & 6.86 & 5.44 & 126.10 & Glutamic acid & 25.01 \\
\hline Methionine & 0.71 & - & - & Glycine & 5.00 \\
\hline Cystine & 0.19 & - & - & Proline & 4.87 \\
\hline Total sulfur amino acids & 0.90 & 3.52 & 25.56 & Serine & 4.19 \\
\hline Phenylalanine & 5.63 & - & - & - & - \\
\hline Tyrosine & 3.01 & - & - & - & - \\
\hline Total aromatic amino acid & 8.64 & 6.80 & 127.05 & - & - \\
\hline Threonine & 4.62 & 4.00 & 115.50 & - & - \\
\hline Valine & 6.20 & 3.50 & 117.14 & - & - \\
\hline Tryptophan & 1.82 & 0.96 & 189.58 & - & - \\
\hline Total essential amino acid & 44.38 & - & - & $\begin{array}{l}\text { Total non-essential } \\
\text { amino acid }\end{array}$ & 55.62 \\
\hline Chemical score & \multicolumn{5}{|l|}{$25.56 \%$} \\
\hline $1^{\text {st }}$ Limiting amino acid & \multicolumn{5}{|c|}{ Methionine + Cystine } \\
\hline $2^{\text {nd }}$ Limitingamino acid & \multicolumn{5}{|l|}{ Leucine (98.70) } \\
\hline Protein efficiency ratio (PER) & \multicolumn{5}{|l|}{2.37} \\
\hline
\end{tabular}

Table 3. Functional properties of garden cress seed protein isolate (GcPI) *.

\begin{tabular}{|c|c|c|c|c|}
\hline GcPI & Water absorption (\%) & Fat absorption (\%) & Emulsification capacity at $\mathrm{pH}=9(\mathrm{~mL}$ oil $/ \mathrm{g}$ protein $)$ & Foam capacity at $\mathrm{pH}=9(\%)$ \\
\hline & $229.0 \pm 2.89$ & $350.2 \pm 0.99$ & $65.00 \pm 3.20$ & $39.50 \pm 1.57$ \\
\hline
\end{tabular}

* Means \pm SD; values are means of three determinations.

Ash content indicates that garden cress seed is an appreciable source of minerals. Potassium, phosphorus, magnesium and calcium constituted the major minerals in garden cress seed 1251.0, 610.6, 346.4 and $340.3 \mathrm{mg} / 100$ g dry weight basis, respectively. Sodium, iron, copper and zinc were found in low quantities in garden cress seed. Mineral content of garden cress is in agreement with those reported earlier for $L$. sativum $[8,40]$. These mineral values were generally within the range reported for most grain legumes [41,42], and similar to those reported for vegetables [43]. While grain legumes represent useful sources of desirable minerals, they are usually less biologically available than those from animal origin [44]. Defatting process resulted in significant $(p<0.05)$ increase in the mineral content as compared to full fat flour. The highest levels of mineral were found in garden cress meal, while the lowest concentrations of mineral were observed in protein isolate. These findings are in agreement with those obtained by Egbekun and Ehieze [45] who reported that defatting of beniseed (Sesamumindicum L.) increased mineral contents of defatted flour.

\subsection{Amino acid composition and biological values of garden cress seed protein isolate}

The nutritional quality of a protein is principally governed by its amino acid composition. Table 2 shows the amino acid composition and protein nutritional quality of garden cress protein isolate. Results indicated that total essential amino acids of garden cress protein isolate formed $44.38 \%$ of the total amino acid content. With the exception of sulfur containing amino acids, every essential amino acid of garden cress protein isolate were higher than their corresponding contents in the reference protein [27] pattern for children. The amino acid profile showed that valine, lysine and leucine had the highest values $6.20,6.86$ and $6.95 \mathrm{~g} / 100 \mathrm{~g}$ protein, respectively; however, the lowest values were recorded for methionine and cysteine 0.71 and 0.19 , respectively. Therefore, garden cress protein could very well complement those protein sources that are low in valine, lysine and leucine acids. Total amount of nonessential amino acids represented $55.62 \%$ of the total amino acid content. Glutamic acid and aspartic acid were found to be the major non-essential amino acids in garden cress protein isolate 25.01 and $12.71 \%$, respectively. There is no previous report on amino acid composition of garden cress protein isolate; however, these findings confirmed those reported for garden cress seeds by Sharma and Agarwal [39] and Zia-Ul-Haq et al. [40]. These results also agreed with those reported for some legume seed proteins and oil seeds $[27,46]$ that plant proteins are limited by sulphur containing amino acids.

The results presented in Table 2 show that histidine scored significantly $(\mathrm{p}<0.05)$ the highest chemical protein score 258.50, based on the FAO/WHO/UNU [27] reference. The results also indicated relatively high chemical protein scores $127.05,126.10,189.58,119.25,117.14,115.50$ and 98.70 for total aromatic amino acids, lysine, typtophan, isoleucine, valine, threonine and leucine, respectively. In contrast sulfur containing amino acids (Methionine + Cystine) had significantly the lowest score 25.56 and were predicted as the first limiting amino acids of garden cress protein isolate. These findings agreed well with those reported by Sharma and Agarwal [39] and Zia-Ul-Haq et al., [40], who showed that methionine and cysteine recorded the lowest values of essential amino acids for garden cress seeds.

The protein nutritional quality parameters of garden cress protein are presented in Table 2. Sulfur containing amino acids and leucine were the first and second limiting amino acids, 25.56 and 98.70 , respectively. This, therefore, implies that any dietary formulation involving this protein feed/food resource would be mindful of the dietary supply of these amino acids. Protein efficiency ratio (PER) of garden cress protein was 2.37 Similar PER values were reported by Saleh and El-Adawy [47] and Khattab et al., [48] for chickpea and Egyptian cowpea. The high levels of essential amino acids of garden cress seed protein explains the high biological values of garden cress protein

\subsection{Functional properties of garden cress seed protein isolate}

The water absorption capacity (WAC) of garden cress protein isolate was of $229 \mathrm{~mL} \mathrm{H}_{2} \mathrm{O} / 100 \mathrm{~g}$ (Table 3). This is likely due to the fact that the protein isolate has a great ability to swell, dissociate and unfold exposing additional binding sites, whereas the carbohydrates and other non-protein components may impair it [49]. 
Table 4. Fatty acid compositions and tocopherols of garden cress seed oil.

\begin{tabular}{|c|c|}
\hline Fatty acid $(\%) *$ & Garden cress oil \\
\hline C8:0 Caprylic acid & Not detected \\
\hline C10:0 Capric acid & Not detected \\
\hline C12:0 Lauric acid & Not detected \\
\hline C14:0 Myristic acid & Not detected \\
\hline C16:0 Palmitic acid & 9.10 \\
\hline C16:1 Palmitoleic acid & 0.16 \\
\hline C18:0 Stearic acid & 4.40 \\
\hline C18:1 Oleic acid & 26.42 \\
\hline C18:2 Linoleic acid & 8.64 \\
\hline C18:3 linolenic acid & 41.17 \\
\hline C20:0 Arachidic & 3.57 \\
\hline C20:1 Arachidonic acid & Not detected \\
\hline C22:0 Behenic acid & Not detected \\
\hline C22:1 Erucic acid & 6.56 \\
\hline SAFA & 17.07 \\
\hline MUFA & 33.15 \\
\hline PUFA & 49.81 \\
\hline \multicolumn{2}{|l|}{ Tocopherols (mg/100 g) } \\
\hline$\alpha$-Tocopherol & $18.49 \pm 0.86$ \\
\hline$\beta$-Tocopherol & Not detected \\
\hline$\gamma$-Tocopherol & $115.47 \pm 2.79$ \\
\hline$\delta$-Tocopherol & $16.50 \pm 1.14$ \\
\hline Total & 150.46 \\
\hline
\end{tabular}

*SAFA: Saturated fatty acids; MUFA: Monounsaturated fatty acids; PUFA: Polyunsaturated fatty acids.

The WAC value obtained for garden cress protein isolate is similar to those values were obtained by El-Adawy et al., [50] and Ogunwolu et al., [51] for bitter lupin protein isolate and cashew nut, respectively $\left(2.12\right.$ and $\left.2.20 \mathrm{~mL} \mathrm{H}_{2} \mathrm{O} / \mathrm{g}\right)$, processed by the same method. High WAC of garden cress protein isolate makes this protein a potential ingredient in meat, bread, and cakes industries. Oil absorption capacity (OAC) of garden cress protein isolate was found to be $3.50 \mathrm{~mL}$ oil/g (Table 3), and was similar to that was obtained by El-Adawy et al., [50] for bitter lupin protein isolate $(3.73 \mathrm{~mL}$ oil $/ \mathrm{g})$. While this OAC value was lower to that of cashew nut $(4.42 \mathrm{~mL}$ oil/g), as reported by Ogunwolu et al., [51]. According to Kinsella [49], the ability of protein to bind fat is very important for such applications as meat replacement and extenders, principally because it enhances flavour retention, and reputedly improves mouth feel. Also, high OAC of garden cress protein isolate makes it a good ingredient for the cold meat industry, particularly for sausages, where the protein can bridge the fat and water in these products. Proteins generally possess hydrophobic and hydrophilic properties due to different types of amino acids. This causes protein interaction with both oil and water molecules and the proteins can act as emulsifiers. Emulsion capacity depends on the hydrophobic-hydrophilic balance, which is affected by $\mathrm{pH}$. At $\mathrm{pH}=9$ emulsifying capacity index (ECI) of garden cress protein isolate was found to be 65.0 $\mathrm{mL}$ oil/g protein (Table 3). The ECI value of Garden cress protein isolate was comparable to that of Lupinusmutabilis seed flours ( $55 \mathrm{~mL}$ oil/g) processed by the same method as reported by Sathe et al. [52]. While the ECI of the garden cress protein isolate is lower to that of bitter lupin protein isolate $(91.6 \mathrm{~mL}$ oil/g), as reported by El-Adawy et al., [50]. At $\mathrm{pH}=9$ foam capacity index (FCI) of garden cress protein isolate was found to be $39.50 \%$ (Table 3). El-Adawy et al. [53], El-Adawy et al., [50] and Ogunwolu et al., [51] found a similar observation for foam capacity of citrus seed flours, bitter lupin protein isolate and cashew nut, respectively. Foam formation is governed by three factors; including transportation, penetration and reorganization of the molecule at the air-water interface. Therefore, to exhibit good foaming, a protein must be capable of migrating at the air-water interface, unfolding and rearranging at the interface [54]. According to Damodaran [55], the foam capacity and stability were enhanced by greater protein concentration, because this increases the viscosity and facilitates the formation of a multilayer, cohesive protein film at the interface.

\subsection{Fatty acid composition garden cress oil}

The results presented in Table 4 show the fatty acid (FA) composition (\%) of garden cress oil. Eight FAs were identified and quantified in garden cress oil sample: palmitic acid (C16:0), palmitoleic acid (C16:1), stearic acid (C18:0), oleic acid (18:1), linoleic acid (18:2), linolenic acid (18:3), arachidic acid (C20:0) and erucic acid (C22:1). Garden cress oil was characterized by the presence of high levels of poly and mono-unsaturated fatty acids of 49.81 and 33.15, respectively. The most prominent fatty acids in Garden cress oil were linolenic acid (41.17\%) and oleic acid $(26.42 \%)$. Moderate amounts of palmitic $(9.10 \%)$, linoleic (8.64 \%), erucic acid $(6.56 \%)$ and stearic acid $(4.40 \%)$ were showed for garden cress oil. The oil also contained trace amounts of C16:1 (0.16 \%) and C20:0 (3.57\%) fatty acids Saturated fatty acids (SFA) represented $17.06 \%$ of total fatty acids for garden cress oil. The content of PUFA was significantly higher than MUFA and SFA content. The results showed that the chromatographic peak areas of linolenic (C18:3) and stearic (C18:0) fatty acids were markedly higher than those obtained by Zia-Ul-Haq et al., [40]. In the same time, the presence of erucic acid (C22:1) in garden cress seeds was not reported by Zia-Ul-Haq et al., [40]. On the other hand, the obtained fatty acid profiles for garden cress oil were similar to those reported by [6].

\subsection{Tocopherol content}

Tocopherols and tocotrienols are derivatives of 2-methyl-6chromanol with a side chain of three terpene units attached at C2. The terpenoid side chain is in saturated form for tocopherol and in unsaturated form for tocotrienols. Both tocopherols and tocotrienols are further divided into individual compounds that are designated by the Greek letter prefixes $\alpha, \beta, \gamma, \delta$ depending on the number and position of methyl substitution on the chromanol ring [56]. Tocopherols are recognised as the principal natural antioxidants in vegetable oils [57]. Table 4 shows the levels of tocopherols in Garden cress seed oil. Total tocopherol content of garden cress oil was $150.46 \mathrm{mg} / 100 \mathrm{~g}$. The $\gamma$-tocopherol was found to be the predominant tocopherol in garden cress oil, represented $76.74 \%$ of the total tocopherol content. $\gamma$-Tocopherol content in vegetable oil is positively correlated with the amount of $\alpha$-linolenic present in it [58]. These findings are consistent with those obtained by Diwakar et al., [6] who reported that $\gamma$-tocopherol is found to be the predominant tocopherol in garden cress seed oil. 
Table 5. Physicochemical properties of garden cress (Lepidiumsativum Linn.) oil and biodiesel a.

\begin{tabular}{llll}
\hline Physicochemical parameters & Garden cress oil b & Garden cress biodiesel b & LSD $(\boldsymbol{p}=\mathbf{0 . 0 5}) \mathbf{c}$ \\
\hline Moisture content, \% & Not detected & Not detected & - \\
Refractive index at $25{ }^{\circ} \mathrm{C}$ & $1.4720 \pm 0.0004$ & $1.4700 \pm 0.0007$ & 0.0012 \\
Specific gravity $(\mathrm{g} / \mathrm{mL})$ & $0.90 \pm 0.11$ & $0.85 \pm 0.16$ & 0.3112 \\
Viscosity $\left(\mathrm{mPa} / \mathrm{s}\right.$ at $\left.30^{\circ} \mathrm{C}\right)$ & $57.4 \pm 2.10$ & $8.50 \pm 0.60$ & 3.500 \\
Acid value $(\mathrm{mg} \mathrm{KOH} / \mathrm{g} \mathrm{Oil)}$ & $1.60 \pm 0.23$ & $0.21 \pm 0.04$ & 0.374 \\
Peroxide value $\left(\mathrm{meq} . \mathrm{O}_{2} / \mathrm{kg}\right)$ & $5.08 \pm 0.28$ & $0.90 \pm 0.10$ & 0.470 \\
Saponification value $(\mathrm{mg} \mathrm{KOH} / \mathrm{g})$ & $180.21 \pm 1.65$ & $182.10 \pm 1.99$ & 4.143 \\
lodine value $(\mathrm{g} \mathrm{I} / 100 \mathrm{~g}$ oil) & $131.5 \pm 1.50$ & $128.00 \pm 1.86$ & 3.830 \\
Biodiesel yield $\%$ & $90.00 \pm 2.33$ & - & - \\
\hline
\end{tabular}

Biodiesel yield \%

Data are expressed as mean \pm SD. Values given represent means of three determinations.

$p \leq 0.05$.

c LSD: Least different significantly at $p \leq 0.05$ according to Duncan's multiple range test.

\subsection{Physicochemical properties of garden cress oil and biodiesel}

Physicochemical properties of garden cress oil and Biodiesel are shown in Table 5. Moisture content of oil and biodiesel was not detected (Table 5), which reflects the quality of oil and biodiesel. Hydrolysis of ester bonds in lipids (lipolysis), resulting in the liberation of free fatty acids, may be caused by enzymatic action or by heat and moisture [57]. The refractive index shows the degree of unsaturation and presence of unusual components such as hydroxyl groups [58]. The refractive index of garden cress oil was 1.4720 which is within the range of edible oils [59].

Based on previous studies on storage stability of biodiesel [60-62], iodine value, peroxide value and the acid number can be used as the indicators of the storage stability of biodiesel. The acid value of garden cress oil was $1.60 \mathrm{mg} \mathrm{KOH} / \mathrm{g}$ oil, this value is in conformity with the specifications of edible oils [59]. The maximum level of acid value of refined; cold pressed and virgin oils were 0.6 and $4.0 \mathrm{mg} \mathrm{KOH} / \mathrm{g}$ oil, respectively [59]. Determination of total acid number is an important test to assess the quality of a particular biodiesel. It can indicate the degree of hydrolysis of the methyl ester, a particularly important aspect when considering storage and transportation as large quantities of free fatty acids can cause corrosion in tanks [63]. Low level of acidity was observed for biodiesel 0.21 $\mathrm{mg} \mathrm{KOH} / \mathrm{g}$ oil. Acid number (mg $\mathrm{KOH} / \mathrm{g}$ oil) for biodiesel should to be lower than $0.50 \mathrm{mg} \mathrm{KOH} / \mathrm{g}$ in both EN 14214 and ASTM D6751 standard fuels. The high FFA content (>1\%; $w: w)$ will happen soap formation and the separation of products will be exceedingly difficult, and as a result, it has low yield of biodiesel product [64]. The iodine value can be used to represent the amount of unsaturated fatty acids in oil. A higher iodine value indicates a higher content of unsaturated fatty acids in oil. The iodine value of the garden cress oil, which was used as the raw oil for the biodiesel production, was $131.5 \mathrm{~g}$ $\mathrm{I}_{2} / 100 \mathrm{~g}$ oil. The iodine value of the biodiesel obtained from garden cress oil was 128.0 g I2/100 g oil. No statistically significant $(p>0.05)$ differences were found between the oil and its biodiesel for iodine values. Since the iodine value is only dependent on the origin of the vegetable oil, the bio-diesel esters made from the same oil should have similar iodine values [19]. The peroxide value is an indicator of the extent of peroxidation of fatty acid oil at its initial stage of storage. Peroxide value (PV) of Garden cress oil was 5.08 meq. $\mathrm{O}_{2} / \mathrm{kg}$, which is less than $10 \mathrm{meq} \mathrm{O}_{2} / \mathrm{Kg}$, and therefore within the acceptable value range for fresh oil [59]. The peroxide value of the biodiesel obtained from garden cress oil was 0.90 meq $\mathrm{O}_{2} / \mathrm{kg}$, the low PV of garden cress biodiesel indicates that it is less prone to oxidative rancidity. The saponification value indicates the amount of saponifiable units (acyl groups) per unit weight of oil. A high saponification value indicates a higher proportion of low molecular weight fatty acids in the oil or vice versa [6]. Saponification value is used for measuring the average molecular weight of oil and expressed in milligrams of potassium hydroxide (mg KOH/g oil). The saponification value of garden cress oil and biodiesel were 180.21 and $182.10 \mathrm{mg}$ $\mathrm{KOH} / \mathrm{g}$, respectively, indicating that the oil and biodiesel of garden cress seed contained high molecular weight mass fatty acids (Table 5). Saponification value is related to the average molecular weight of the sample, but the acids that are present in glycerides or in methyl esters are the same. Only the change of glycerol by methanol is produced. In consequence, the average molecular weight does not change significantly and so it may not be observed changes in the saponification value. Viscosity value of garden cress oil was $57.4 \mathrm{mPa}$.s, while the biodiesel obtained from garden cress oil had significantly $(\mathrm{p}<$ 0.05 ) the lower value $8.50 \mathrm{mPa}$.s. Converting vegetable oils to biodiesel decreases the viscosity and increases the volatility allowing them to be used in diesel engines [65]. The specific gravity of garden cress oil was $0.90 \mathrm{~g} / \mathrm{mL}$, while that of the biodiesel obtained from garden cress oil was $0.85 \mathrm{~g} / \mathrm{mL}$, which confirms with ASTM D6751 standard.

The significant $(\mathrm{p} \leq 0.05)$ decreases in viscosity, acid and peroxide values for biodiesel could be explained by the positive effects of purification and washing processes during the preparation of biodiesel and by the fact that polar molecules dissolve best in polar solvents. Polar molecules can hydrogen bond with polar solvents, such as water, hence increasing their solubility. As shown in Table 5, the biodiesel yield from garden cress oil was $90 \%$. This was similar to those reported by Galadima et al., [66]; Kywe and Myao, [67]. The results of quality assessment tests performed on the biodiesel obtained from garden cress oil revealed that most of the fuel specifications comply with ASTM (American Society for Testing Materials) D 6751 requirements (Table 5).

\section{Conclusions}

In conclusion, the results of this study showed that garden cress (Lepidiumsativum L.) was rich in oil and protein and, considering its fatty acid profile, it lies in linolenic-oleic group. Moderate amounts of erucic acid (6.56\%) were showed for garden cress oil. The oil can be considered as potential, alternate and non-conventional oil and can be used as a new and valuable source of biodiesel. Protein isolated from garden cress seed showed high protein content (86.90\%). High WAC of garden cress protein isolate makes this protein a potential ingredient in meat, bread, and cakes industries. Also, high OAC of garden cress protein isolate makes it a good ingredient for the cold meat industry, particularly for sausages, where the protein can bridge the fat and water in these products. Therefore, the protein isolated from garden cress seed could be a desirable food ingredient and can be used as nutrient substitution or supplementation and as functional agent in food systems.

\section{References}

[1]. Gokavi, S. S.; Malleshi, N. G.; Guo, M. Plant Food. Hum. Nutr, 2004, 59, 105-111.

[2]. Tiwari, P. N.; Kulmi, G. S. J. Med. Arom. Pl. Sci. 2004, 26, 479-481.

[3]. Archana, N. P.; Anita, A. M. Iran J. Pharmacol. Ther. 2006, 5, 55-59. 
[4]. Arkroyd, W. R.; Gopalan, C.; Balasubramanian, S. C. Nutritive value of Indian Foods and the planning of satisfactory diets. Indian Council of Medical Research, N. Delhi, 1966, pp. 64.

[5]. Mathews, S.; Singhal, R. S.; Kulkarni, P. R. Die Nahrung. 1993, 37, 6971.

[6]. Diwakar, B. T.; Dutta, P. K.; Lokesh, B. R.; Naidu, K. A. J. Am. Oil. Chem. Soc. 2010, 87, 539-548.

[7]. Lotfy, M.; Aref, H.; Hussein, A. A. J. Am. Oil. Chem. Soc. 1957, 34, 96100.

[8]. Moser, B. R.; Shah, S. N.; Winkler-Moser, J. K.; Vaughn, S. F.; Evangelista, R. L. Ind. Crop . Prod. 2009, 30, 199-205.

[9]. Green, T. J.; Innis, S. M. Lipids 2000, 35, 607-612.

[10]. Kickler, T. S.; Zinkham, W. H.; Moser, A.; Shankroff, J.; Borel, J.; Moser, H. Biochem. Mol. Med. 1996, 57(2), 125-133.

[11]. Shay, E. G. Biomass Bioenergy 1993, 4, 227-242.

[12]. ASTM Standard specification for biodiesel fuel (B100) blend stock for distillate fuels. In: Annual Book of ASTM Standards, ASTM International, West Conshohocken, Method D6751-08, 2008.

[13]. Ma, F.; Hanna, M. A. Bioresource Technol. 1999, 70(1), 1-5.

[14]. Fukuda, H.; Kondo, A.; Noda, H. J. Biosci. Bioeng. 2001, 92(1), 405-409.

[15]. Demirbas, A. Energy Policy 2007, 35, 4661-4670.

[16]. Christi, Y. Biotechnol. Adv. 2007, 25, 294-306.

[17]. Dorado, M. P.; Ballesteros, E.; Gomez, J.; Lopez, F. L. Fuel 2003, 82, 1311-1315.

[18]. Bligh, E. G.; Dayer, W. J. Can. J. Biochem. Physiol. 1959, 37, 911-917.

[19]. Lang, X.; Dalai, A. K.; Baskhshi, N. N.; Reaney, M. J.; Hertz, P. B. Bioresource Technol. 2010, 80, 53-62.

[20]. Chitra, P.; Venkatachalam, P.; Sampathrajan, A. Energy Sust. Dev. 2005, 9, 13-18.

[21]. Alamu, O. J.; Waheed, M. A.; Jekayinfa, S. O. Energy Sust. Dev. 2007, 11(3), 77-82.

[22]. Ruiz, L. P.; Hove, E. L. J. Sci. Food Agr. 1976, 27, 667-674.

[23]. Abbott, T. P.; Nakamura, L. K.; Buchholz, G. J. Agric. Food Chem. 1991, 39, 1488-1493.

[24]. A. O. A. C Official Methods of Analysis of the Association of Official Analytical Chemists, $17^{\text {th }}$ edn. (Edited by W. Horwitz). Washington, DC, 2000.

[25]. Moore, S, Stein, W. H. Chromatographic determination of amino acids by the use of automatic recording equipment. In, Colowick, S. P.; Kaplan, N. O. (Eds.), Methods in Enzymology, Vol. 6. Academic Press, New York, 1963, pp. 815-860.

[26]. Miller, E. L. J. Sci. Food Agr. 1967, 18, 381-386.

[27]. Energy and protein requirements. Report of a Joint FAO/WHO/UNU Expert Consultation. Geneva, World Health Organization, 1985 (WHO Technical Report Series, No. 724).

[28]. Chavan, J. K.; Heigaard, J. J. Sci. Food Agr. 1981, 32, 857-862.

[29]. Alsmeyer, R. H.; Cunningham, A. E.; Happich, M. L. Food Technol. 1974, 28, 34-40.

[30]. Sosulski, F. W. Cereal Chem. 1962, 39, 344-347.

[31]. Sosulski, F. W.; Humbert, E. S.; Bui Jones, J. D. J. Food Sci. 1976, 41, 1349-1352.

[32]. Beuchat, L. R.; Cherry, J. P.; Quinin, M. R. J. Agric. Food Chem. 1975, 23, 616-620.

[33]. Lawhon, J. T.; Cater, C. M.; Mattil, K. F. J. Food Sci. 1972, 37, 317-321.

[34]. American Oil Chemists Society (AOCS), Determination of tocopherols and tocotrienols in vegetable oils and fats by HPLC. In, Official Methods and Recommended Practices of the American Oil Chemists Society, $5^{\text {th }}$ ed. AOCS, Champaign, IL, 1999, pp. Ce 8-89.

[35]. Saguy, I. S.; Shani, A.; Weinberg, P.; Garti, N. Lebensm-Wiss Technol. 1996, 29, 573-577.

[36]. AOCS. Official Methods and Recommended Practices of the American Oil Chemists' Society. AOCS Press, Champaign, IL, 1993.

[37]. Gomez, K. A.; Gomez, A. A. Statistical procedures for agricultural research. Wiley, New York, 1984.

[38]. Marangoni, A.; Alli, I. J. Sci. Food Agric. 1988, 44, 99-110.

[39]. Sharma, S.; Agarwal, N. Ind. J. Nat. Prod. Res. 2011, 2, 292-297.

[40]. Zia-Ul-Haq. M.; Ahmad, S.; Calani, L.; Mazzeo, T.; Del Rio, D.; Pellegrini, N.; De Feo, V. Molecules 2012, 17, 10306-10321.

[41]. Dairo, F. A. S.; Adanlawo, I. G. Pakistan J. Nutr. 2007, 6(1), 35-39.

[42]. Onibon, V. O.; Abulude, F. O.; Lawal, L. O. J. Food Agr. 2007, 5(2), 120122.

[43]. Aletor, O. Chemical Composition of Common Leafy Vegetables and Functional Properties of Their Leaf Protein Concentrates. M. Tech. thesis, Department of Chemistry, The Federal University of Technology, Akure, Nigeria, 1999, pp. 95-99.

[44]. O’Del, B. L. Am. J. Clin. Nutr. 1969, 22, 1315-1322.

[45]. Egbekun, M. K.; Ehieze, M. U. Plant Foods Human Nutr. 1997, 51, 3541.

[46]. Charan, U. D.; McKenzie, D. B.; Shahidi, S. Food Chem. 2001, 74, 177 187.

[47]. Saleh, A. A, El-Adawy, T. A. J. Saudi Soc. Food Nutr. 2006, 1(1), 18-29.

[48]. Khattab, R. Y.; Arntfield, S. D.; Nyachoti, C. M. Food Sci Technol. 2009, 42,1107-1112.

[49]. Kinsella, J. E. J. Am. Oil Chem. Soc. 1979, 56, 242-258.

[50]. El-Adawy, T. A.; Rahma, E. H.; El-Bedawey, A.; Gafar, A. F. Food Chem. 2001, 74, 455-462.
[51]. Ogunwolu, S. O.; Henshaw, F. H.; Hans-Peter, M.; Santros, A.; Awonorin, S. O. Food Chem. 2009, 115, 852-858.

[52]. Sathe, S. K.; Deshpande, S. S.; Salunkhe, D. K. J. Food Sci. 1982, 47, 491497.

[53]. El-Adawy, T. A.; Rahma, E. H.; El-Bedawy, A. A.; Gafar, A. M. Nahrung. 1999, 43(6), 379-384.

[54]. Halling, P. J. CRC. Cr. Rev. Food Sci. 1981, 12, 155-203.

[55]. Damodaran, S. Food proteins, An overview. In S. Damodaran\& A. Paraf (Eds.), Food proteins and their applications, New York, Marcel Dekker, 1997, pp. 1-21.

[56]. Gregory. III. J. Vitamins, F. in, Food Chemistry (Ed. O. R. Fennema). Marcel Dekker, New York, 1996. pp. 531-616.

[57]. Nawar, W. W. Lipids. In, Fennema, O. R. (Ed.) Food Chemistry. (3rd edition), Marcel Dekker, Inc. , New York, USA, 1996, pp 225-319.

[58]. Pearson, D. (1981). The chemical analysis of foods, $7^{\text {th }}$ edn. Churchill Livingstone, Edinburgh, pp 504-530.

[59]. Codex Alimentarius. Codex standard for named vegetable oils, CODEX STAN 210-1999, Page 1 of 16 Adopted 1999. Revisions 2001, 2003, 2009. Amendment 2005, 2011.

[60]. Ryan, T.; Dodge, L. G.; Callahan, T. J. J. Am. Oil. Chem. Soc. 1984, 61, 1610-1619.

[61]. Liu, H. R.; White, P. J. J. Am. Oil Chem. Soc. 1992, 69, 528-532.

[62]. Liu, H. R.; White, P. J. J. Am. Oil Chem. Soc. 1992, 69, 533-537.

[63]. Wang, H.; Tang, H.; Wilson, J. J. Am. Oil Chem. Soc. 2008, 85, 10831086.

[64]. Crabbe, E.; Nolasco-Hipolito, C. N.; Kobayashi, G.; Sonomoto, K.; Ishizaki, A. Process Biochem. 2001, 37, 65-71.

[65]. Balat, M.; Balat, H. Appl. Energy 2010, 87(6), 1815-1835.

[66]. Galadima, A.; Garba, Z. N.; Ibrahim, B. M. Int. J. Pure Applied Sci. 2008 2, 138-144.

[67]. Kywe, T. T.; Myao M. World Acad. Sci. Eng. Tech. 2009, 26, 477-483. 